\title{
ЛІНГВАЛЬНІ ТА КОГНІТИВНІ ОСОБЛИВОСТІ МЕТАФОРИ У ПОЕЗІЇ СЕМЮЕЛА ТЕЙЛОРА КОЛРІДЖА
}

\begin{abstract}
Анотація. Пропонована стаття присвячена дослідженню лінгвальних та когнітивних особливостей художньої метафори у поезії Семюела Тейлора Колріджа. Актуальність та новизна обраного предмету аналізу полягає у тому, що метафорика англійського поета Семюела Тейлора Колріджа не була об’єктом особливого наукового інтересу, тим паче ії аналіз з перспективи застосування корпусних технологій та спеціальних програм семантичного аналізу тексту. Відповідно метою ціеї статті є продемонструвати потенціал та продуктивність застосування програми Tropes для виявлення метафоричної структури та змістового наповнення поетичної концептуальної системи Семюела Тейлора Колріджа. Виявлено концептуальні системи, представлені вербальними елементами відповідних денотативних полів та здійснено аналіз основних метафоричних моделей концептуалізації визначених концептуальних сфер.
\end{abstract}

Ключові слова: Семюел Тейлор Колрідж, художня метафора, метафорична модель, корпусний підхід, програма семантичного аналізу тексту Tropes.

Romanyshyn Nataliia, Oleksha Kateryna Lviv Polytechnic National University

\section{LINGUAL AND COGNITIVE FEATURES OF METAPHOR IN THE POETRY OF SAMUEL TAYLOR COLLAGE}

Summary. The proposed article is devoted to the study of linguistic and cognitive features of artistic metaphor in the poetry of Samuel Taylor Coleridge. The relevance and novelty of the chosen subject of analysis is that the metaphor of the English poet Samuel Taylor Coleridge was not the object of special scientific interest, especially its analysis from the perspective of corpus technology and special programs of text semantics analysis. Accordingly, the aim of this article is to demonstrate the potential and productivity of using the Tropes program to identify the metaphorical structure and content of the poetic conceptual system of Samuel Taylor Coleridge. Using the Tropes program, conceptual systems represented by verbal elements of the corresponding denotative fields were identified; an analysis of the distribution of verbal elements within the selected metaphorical micro contexts was carried out, which allowed to establish the main ways of conceptualizing the poetic reality, characteristic of the author; the dominant conceptual spheres of the author's poetic discourse were determined; the frequency of key lexical units involved in the creation of metaphors was studied; the analysis of the basic metaphorical models of conceptualization of the certain conceptual spheres was performed. Quantitative data obtained during the application of appropriate tools of computer analysis of the compiled author's poetic corpus, allowed to cover the maximum volume of contexts of metaphorization and contribute to the achievement of maximum objectivity of research. As a result of the analysis we come to the conclusion about the decisive role of metaphor in the poetic picture of the world of Samuel Taylor Coleridge. Productivity of basic metaphorical models that reflect the individual-author's rethinking of traditional, archetypal imagery, the dominance of anthropocentric metaphorical worldview, the predominance of metaphor-personification, the complexity of the structure of metaphor. Quantitative data obtained during the application of appropriate tools of computer analysis of the concluded author's poetic corpus, allowed us to cover the maximum volume of contexts of metaphorization and contributed to the achievement of maximum objectivity of research.

Keywords: Samuel Taylor Coleridge, artistic metaphor, metaphorical model, corpus approach, text semantics analysis program Tropes.

$\Pi^{\circ}$ остановка проблеми. Постать англійського поета-романтика Семюела Тейлора Колріджа майже одностайно вважаеться однією з найунікальніших і найсуперечливіших. Сучасна критична рецепщія поетичних надбань Колріджа наголошуе на вагомому впливові творчості поета на розвиток англомовної літератури [7; 11]. Дослідження творів Колріджа є інтердисциплінарними, оскільки основна увага в них присвячена різноманітним аспектам тематики поезії автора, їі філософським засадам, що охоплюють проблематику людської екзистенції, культури, релігії, сутність понять свободи і залежності тощо $[6 ; 9 ; 10]$.

У працях дослідників творчості Колріджа лейтмотивом звучить теза про неординарну креативну силу фантазії поета, багатозначність і складність його образів [3; 5, с. 255-267]. Однак ідіостилістична специфіка творів поета охоплена недостатньо, особливо стосовно розкриття лінгвокогнітивних параметрів художньої концептуалізації та метафоризації як способу реконструкції індивідуальної метафоричної картини світу [4], що відбивае регулярність і продуктивність певних метафоричних моделей, закладених у поняттєвій системі людського розуму, які експлікуються в мовно-естетичних формах художнього/ поетичного тексту.

Аналіз останніх досліджень та публікацій. У сучасній стилістиці та когнітивній поетиці теза про те, що метафори у художніх текстах письменника або поета проявляють специфріку концептосфери та творчого методу автора вже стали аксіоматичними $[1 ; 2]$. У літературно-художньому творі присутні як універсальні метафори, що відображають загальнолюдські знання про навколишній 
світ, так і уявлення, які властиві лише певному автору. Ступінь взаємозалежності універсальних і індивідуально-авторських знань, представлених метафрорично, в художній картині світу тексту може бути різна, що відображено у відборі лексичних засобів, їх вмотивованості з комунікативної точки зору. Авторська метафорична система є синтезом компонентів загальнонаціонального образу світу i індивідуальних, часом парадоксальних, уявлень автора, специфіки його художньої концептуалізації, що містить безліч особистісних смислів, які дозволяють йому вийти за межі наочного і чуттєвого досвіду. Реконструкція художньо-поетичної картини можлива на основі авторської метафоричної системи, описавши яку, робимо висновок про відбитий у свідомості фррагмент буття, осмислений в естетичних категоріях, заданих відповідним жанром словесного мистецтва.

У прагненні максимально охопити метафроричні контексти та досягти об'ективності аналізу науковці розробляють дієвий інструментарій семантичного аналізу авторських текстів. Активне та продуктивне залучення корпусних технологій до аналізу авторської метафоричної сорери є яскравим свідченням процесу інтеграції семантикокогнітивних та кількісних методів опрацювання різножанрових текстів [8], зокрема художніх.

Метафорика англійського поета Семюела Тейлора Колріджа не була об'єктом особливого наукового інтересу, тим паче їі аналіз з перспективи застосування корпусних технологій та спеціальних програм семантичного аналізу тексту.

Відповідно, метою цієї статті є продемонструвати потенщіал та продуктивність застосування програми Tropes для виявлення метафоричної структури та змістового наповнення поетичної концептуальної системи Семюела Тейлора Колріджа.
А також розкрити лінгвальні та когнітивні механізми метадроризації у поетичному дискурсі автора.

Виклад основного матеріалу дослідження. Застосувавши вище вказану програму для встановлення авторських метафоричних моделей і їхнього змістового наповнення в ракурсі когнітивно-семантичного аналізу, ми здійснили наступні етапи: 1) на певному корпусі текстів шляхом суцільної вибірки виявили метафроричні контексти та з'ясували, реалізацією яких концептів вони е; 2) визначили метадроричні реалізації даного концепту; 3) на основі аналізу виявлених метафоричних концептів установили їхні лексико-граматичні та стилістичні особливості в межax досліджуваного корпусу текстів; 4) здійснили опис домінантних метафоричних моделей.

У процесі семантико-когнітивного аналізу художньої метафорики поезії Семюела Тейлора Колріджа із застосуванням програми Tropes було виявлено концептуальні системи, представлені вербальними елементами відповідних денотативних полів (редерентних полів), серед яких найчастотнішими виявились сорера людської психо-емоційної діяльності, людська тілесність та навколишне середовище/природа. Дані, отримані в результаті застосування програми, дозволяють виявити лексичну наповненість кожного 3 визначених редерентних полів, встановити частотність та дистрибуцію лексичних елементів, які вербалізують відповідну референтну область, проаналізувати контекстне оточення виділених вербальних елементів.

Аналіз дистрибуції вербальних елементів у межах мікроконтекстів дозволяе встановити основні способи концептуалізації поетичної дійсності, характерні для автора: кохання - тіло душа - жінка; музика - тіло - розум - природа -

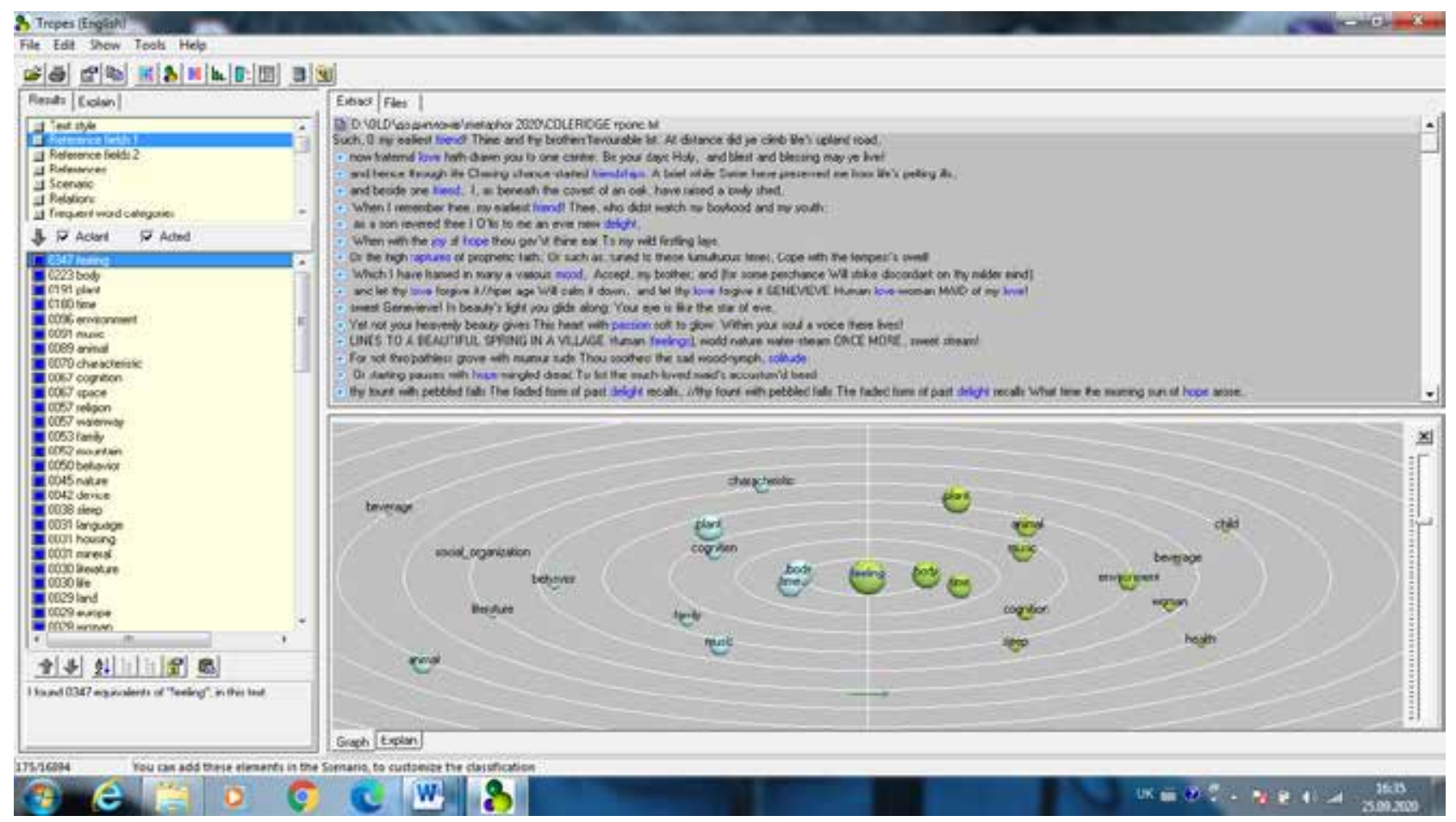

Рис. 1. Частотність та дистрибуція мовних засобів метафоризації поетичних концептів (денотативне поле емоції)

Джерело: розроблено авторали 


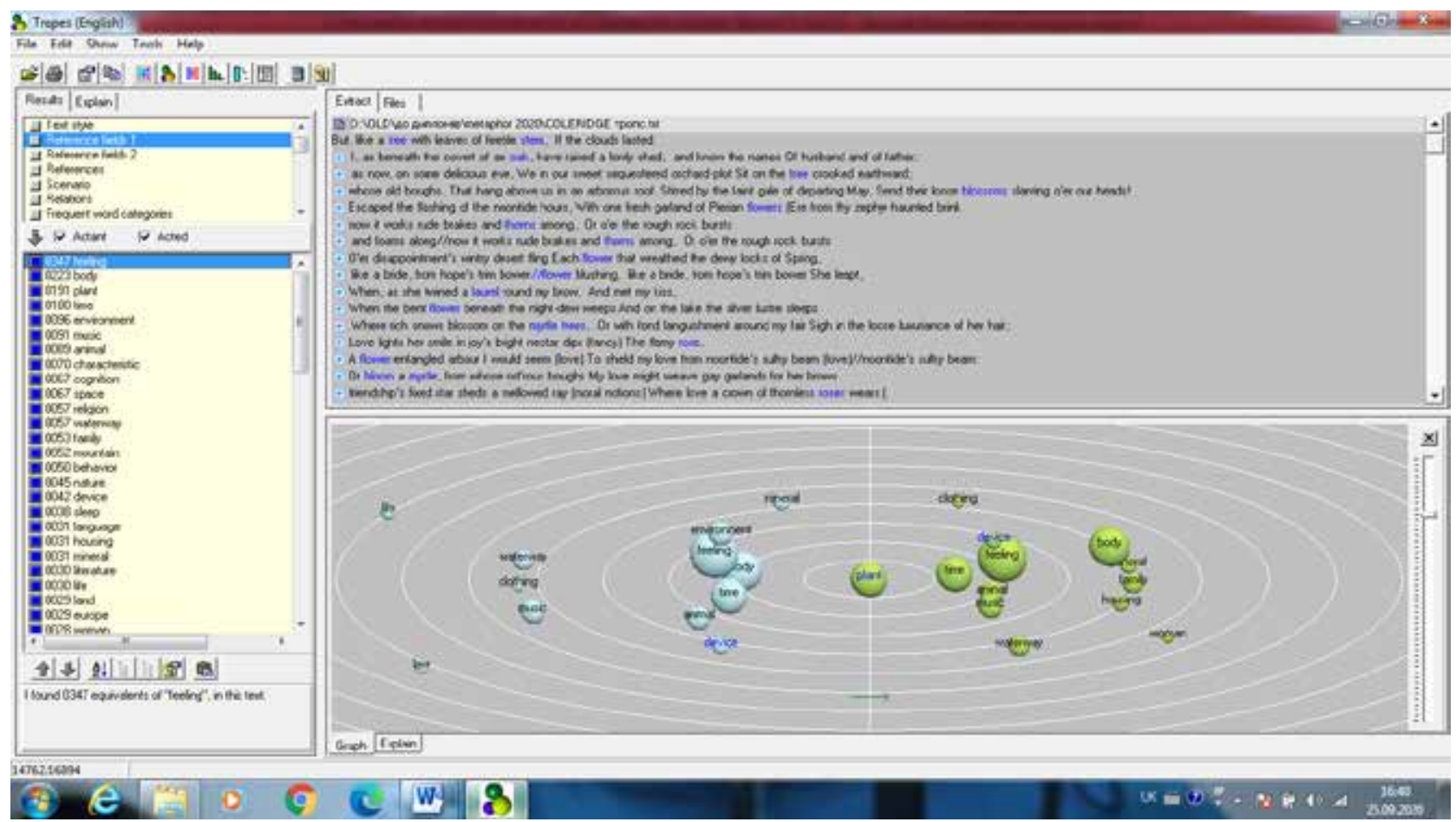

Рис. 2. Частотність та дистрибуція мовних засобів метафоризації поетичних концептів (денотативна сфера «природа»)

Джерело: розроблено авторами

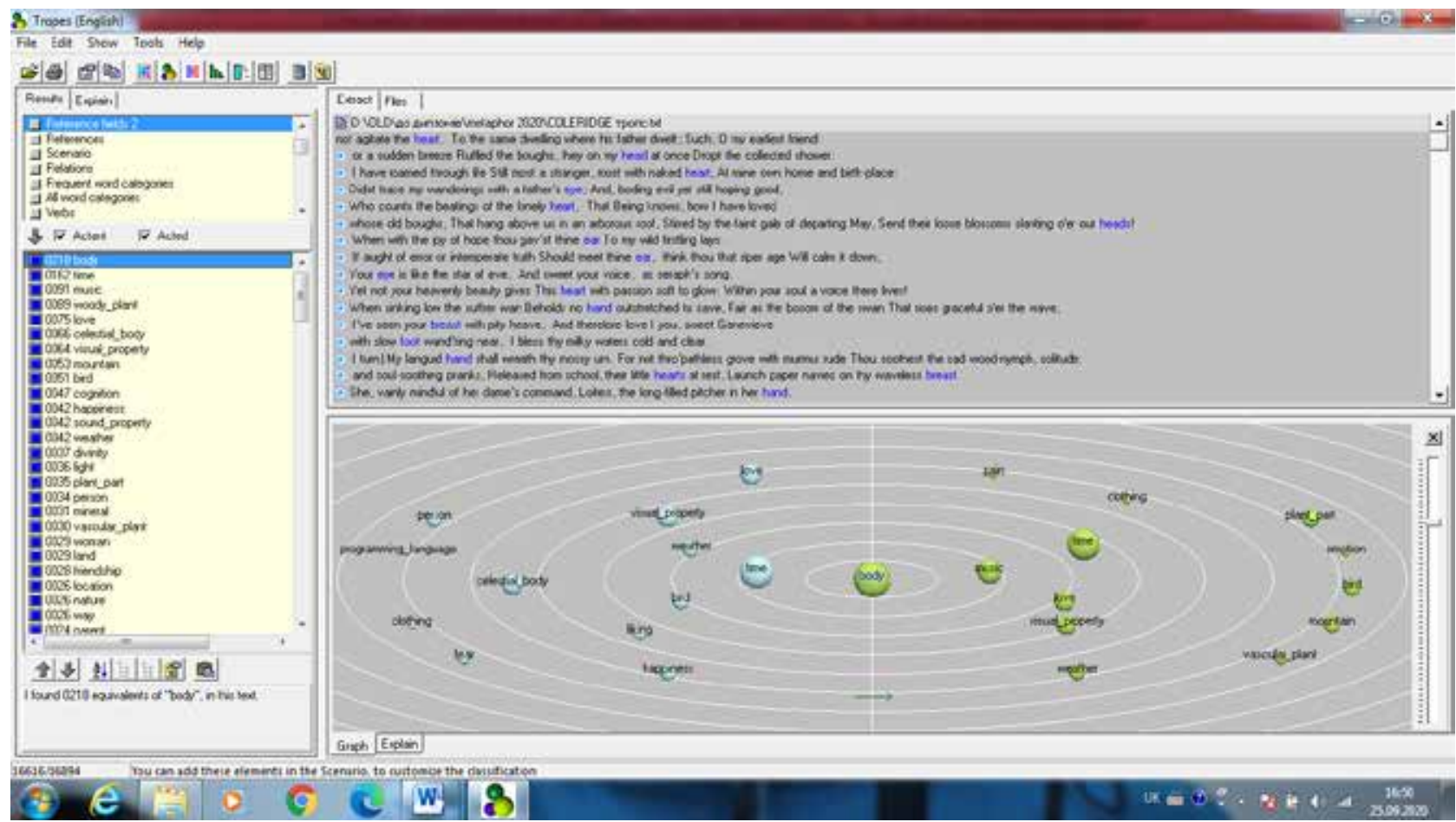

Рис. 3. Частотність та дистрибуція мовних засобів метафоризації поетичних концептів (денотативна сфера «тіло»)

Джерело: розроблено авторами

сенсорні відчуття; життя - розум - природа тощо. В результаті аналізу було також встановлено відповідні підкатегорії у системі виділених рефрерентних полів, наприклад «Людина: жінка: дитина», «Сім'я: чоловік: жінка: діти» та проаналізовано характер дистрибуції вербалізаторів відповідних редерентно-концептуальних полів у тексті. За результатами такого алгоритму аналізу було встановлено, що найбільш рівномірно представленими в корпусі поетичних текстів С.Т. Колріджа є мовні елементи референтних полів "людина", «почуття», «природа, середовище», що засвідчує 


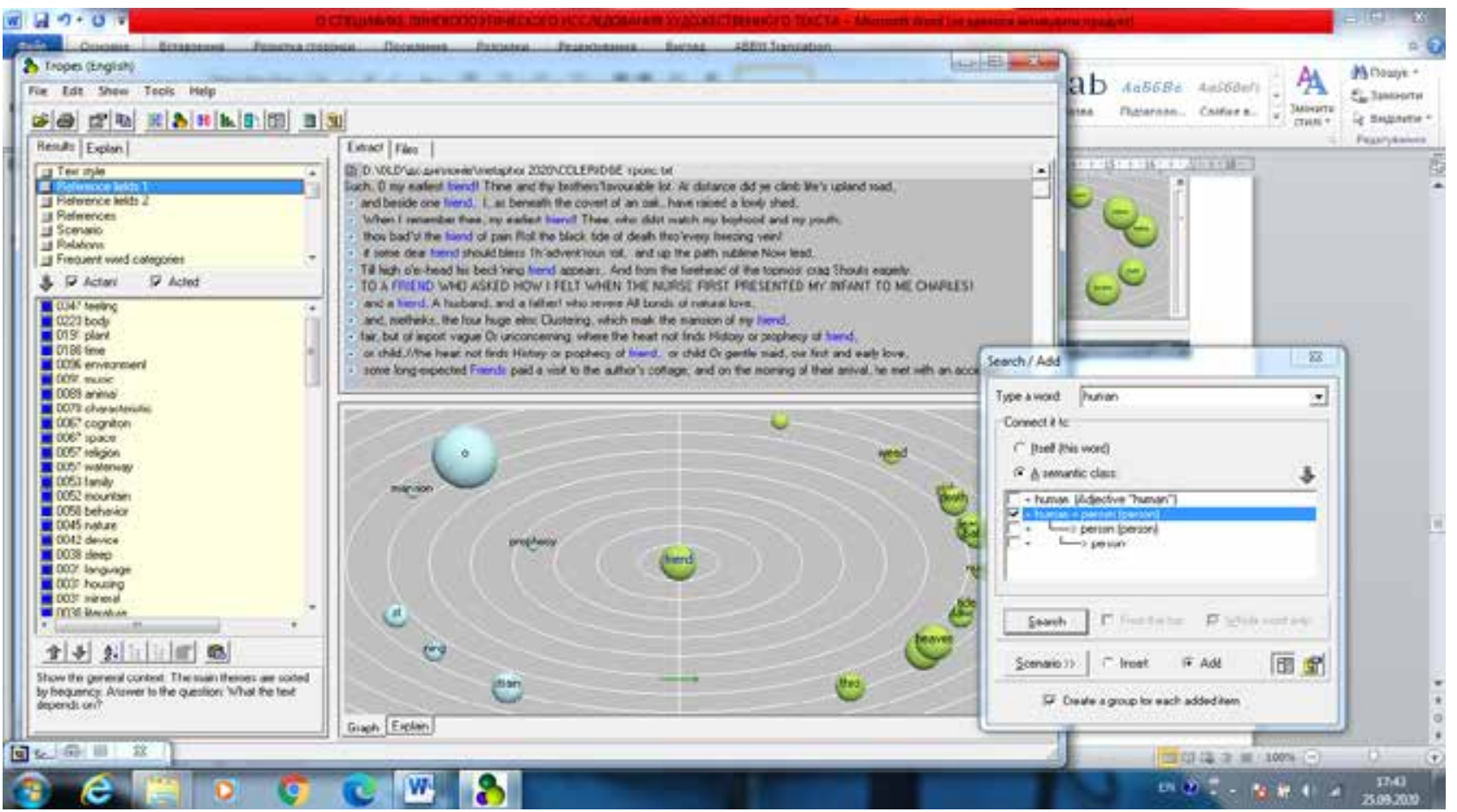

Рис. 4. Характер розподілу та співвідношення вербалізаторів референтно-концептуальних полів (Людина)

Джерело: розроблено авторами

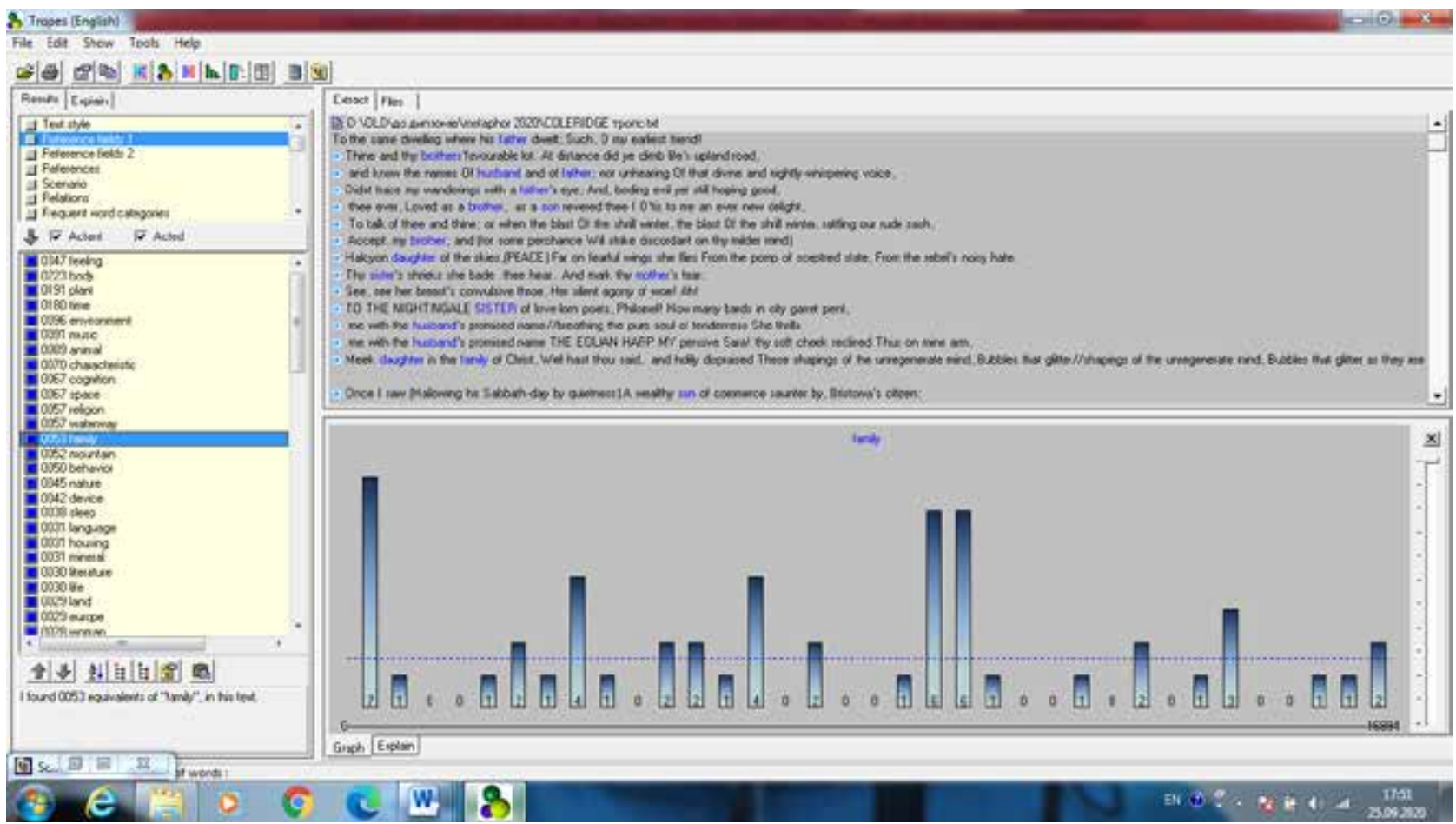

Рис. 5. Характер розподілу та співвідношення вербалізаторів референтно-концептуальних полів (Сім'я)

Джерело: розроблено авторами

високу щільність репрезентащії відповідних концептів у поетичній картині світу автора.

Однак, дослідження вказуе, що застосування програми є обмеженим і часто не висвітлюе об'єктивних процесів та механізмів аналогово-асоціативних кореляцій метафоричних концептів.
Тому аналіз за допомогою програмних засобів був доповнений методом семантичного групування вербалізаторів відповідних референтних полів. Визначені редерентні поля були згруповані у наступні концептуальні сорери, структуру яких можна схематично представити наступним чином (рис. 7). 


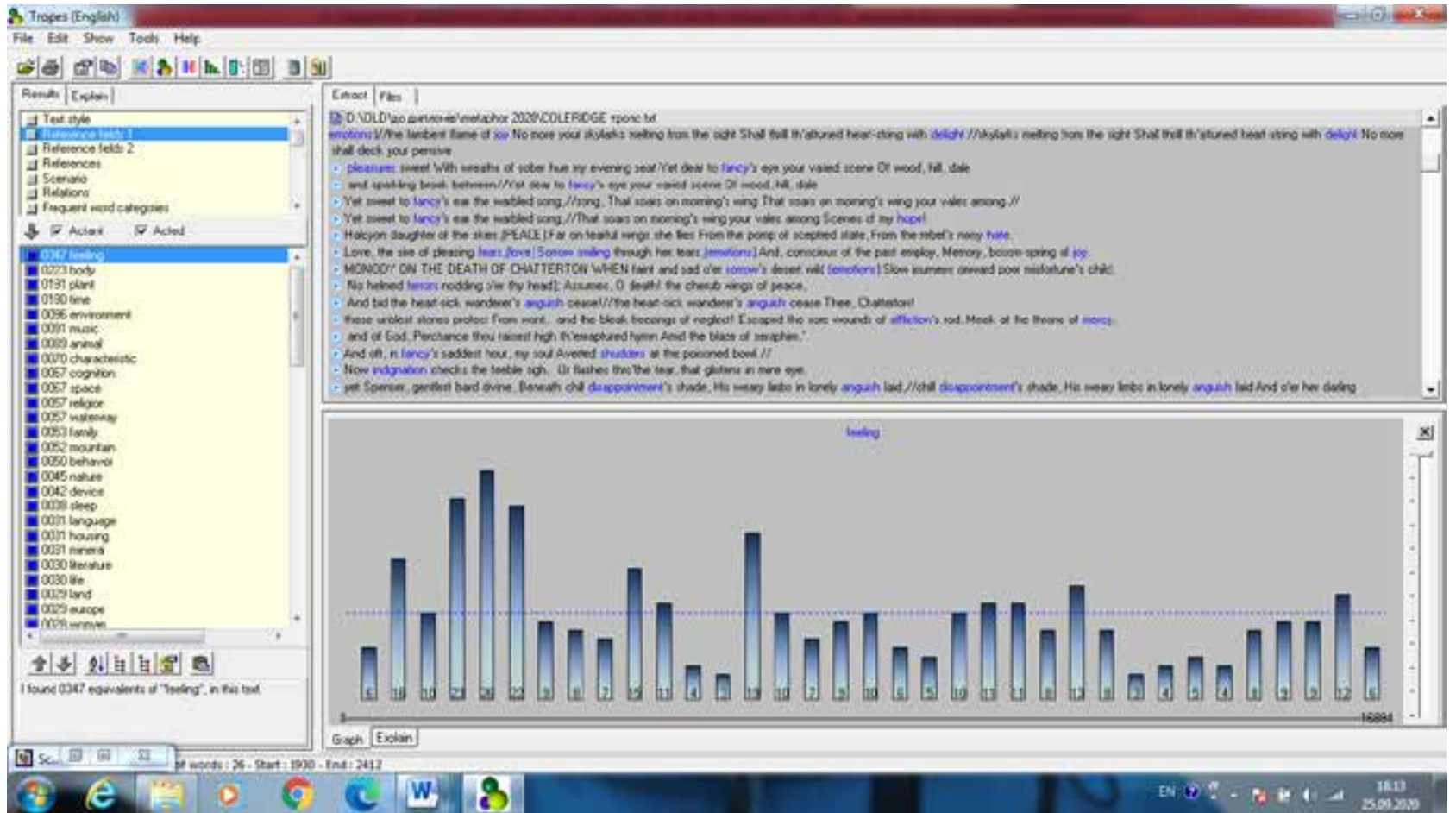

Рис. 6. Характер, частота, розподіл та співвідношення вербалізаторів референтно-концептуальних полів (Людина, почуття, природа)

Джерело: розроблено авторами

\begin{tabular}{|c|c|c|c|c|c|}
\hline HUMAN & WORLD & LIFE & SOCIETY & $\begin{array}{l}\text { ABSTRACT } \\
\text { NOTIONS }\end{array}$ & GOD \\
\hline $\begin{array}{l}\text { - human } \\
\text { general } \\
\text { - human } \\
\text { states and } \\
\text { emotions/ } \\
\text { feelings } \\
\text { - soul/heart } \\
\text { - age } \\
\text { - female } \\
\text { beauty } \\
\text { - poet/geni } \\
\text { us } \\
\text { - body } \\
\text { - man }\end{array}$ & $\begin{array}{l}\text {-world/ nature } \\
\text { (general) } \\
\text { •world } \\
\text { /environment } \\
\text { (physical: } \\
\text { landscape and } \\
\text { its constituents; } \\
\text { social: :home) } \\
\text { - natural powers } \\
\text { (water: stream, } \\
\text { river, sea, } \\
\text { ocean; air: air, } \\
\text { wind, clouds; } \\
\text { fire) } \\
\text {-natural } \\
\text { elements } \\
\text { (celestial } \\
\text { bodies: sun, } \\
\text { moon, stars) } \\
\text {-natural } \\
\text { elements } \\
\text { (mountains, } \\
\text { hills) } \\
\text {-seasons } \\
\text {-creatures } \\
\text {-time and } \\
\text { phenomena } \\
\text { (day, night, } \\
\text { sunset, sunrise, } \\
\text { light, darkness, } \\
\text { colours) }\end{array}$ & $\begin{array}{l}\text { - life } \\
\text { general } \\
\text { - aspects of } \\
\text { life } \\
\text { - life stages }\end{array}$ & $\begin{array}{l}\text { - society } \\
\text { (general) } \\
\text { - social } \\
\text { relations } \\
\text { - family } \\
\text { - country/st } \\
\text { ate }\end{array}$ & $\begin{array}{l}\text { - hope } \\
\text { - fancy } \\
\text { - memory } \\
\text { - love } \\
\text { - poetry } \\
\text { - moral } \\
\text { notions } \\
\text { - other }\end{array}$ & $\begin{array}{l}\text { - GOD } \\
\text { (GENERAL } \\
\text { ) }\end{array}$ \\
\hline
\end{tabular}

Рис. 7. Художньо-поетичні концептосфери поетичного дискурсу Семюела Тейлора Колріджа: структура 
Наступним кроком аналізу було встановлення специфіки метафоризації визначених концептів у межах загальних концептуальних полів. Емпіричний матеріал в подальшому був розподілений на підкорпуси, у яких узагальнено контексти метафроризації виділених концептуальних мікрополів у межах загальних концептуальних областей. Вибірку метафор було проаналізовано за семантичними та граматичними параметрами.

Частотний аналіз лексико-граматичних параметрів ідіостилю Семюела Тейлора Колріджа до- зволив встановити відносний розподіл основних частин мови, що беруть участь у процесах художньо-поетичної метафоризації. Найчастотнішими лексико-семантичними класами слів виявилися дієслова та прикметники, відносно рівномірно розподілені у корпусі текстів (рис. 8-9).

Дієсловами, що зазнають метафоризащї, є лексеми, які належать до лексико-семантичних груп сенсорних відчуттів, когнітивної діяльності, психоемоційної діяльності, стану. Виявлено контексти 3 дієслівною метафророю-персоніфрікаією на основі

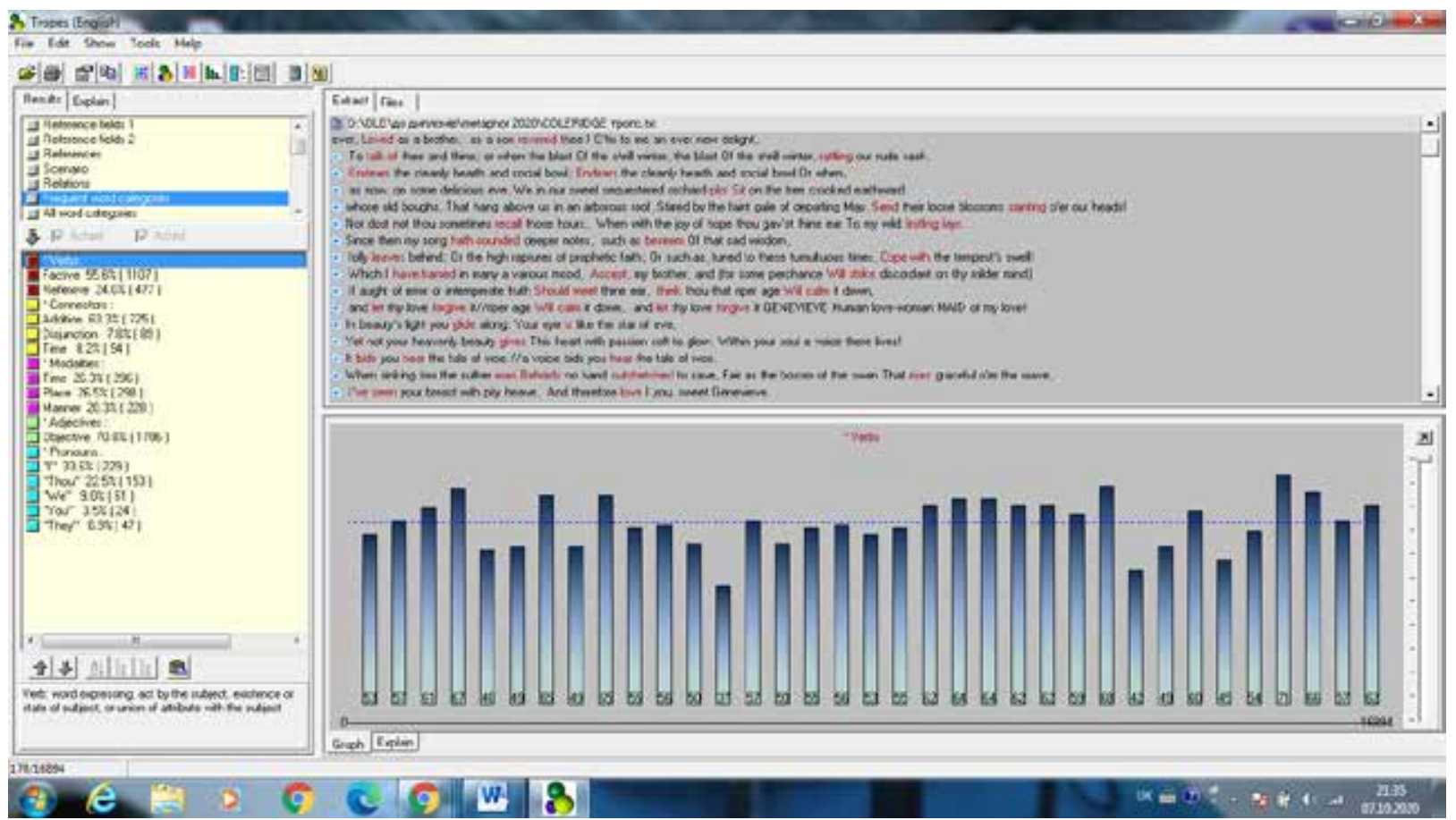

Рис. 8. Частотність дієслівних метафор у поезї Семюела Тейлора Колріджа

Джерело: розроблено авторами

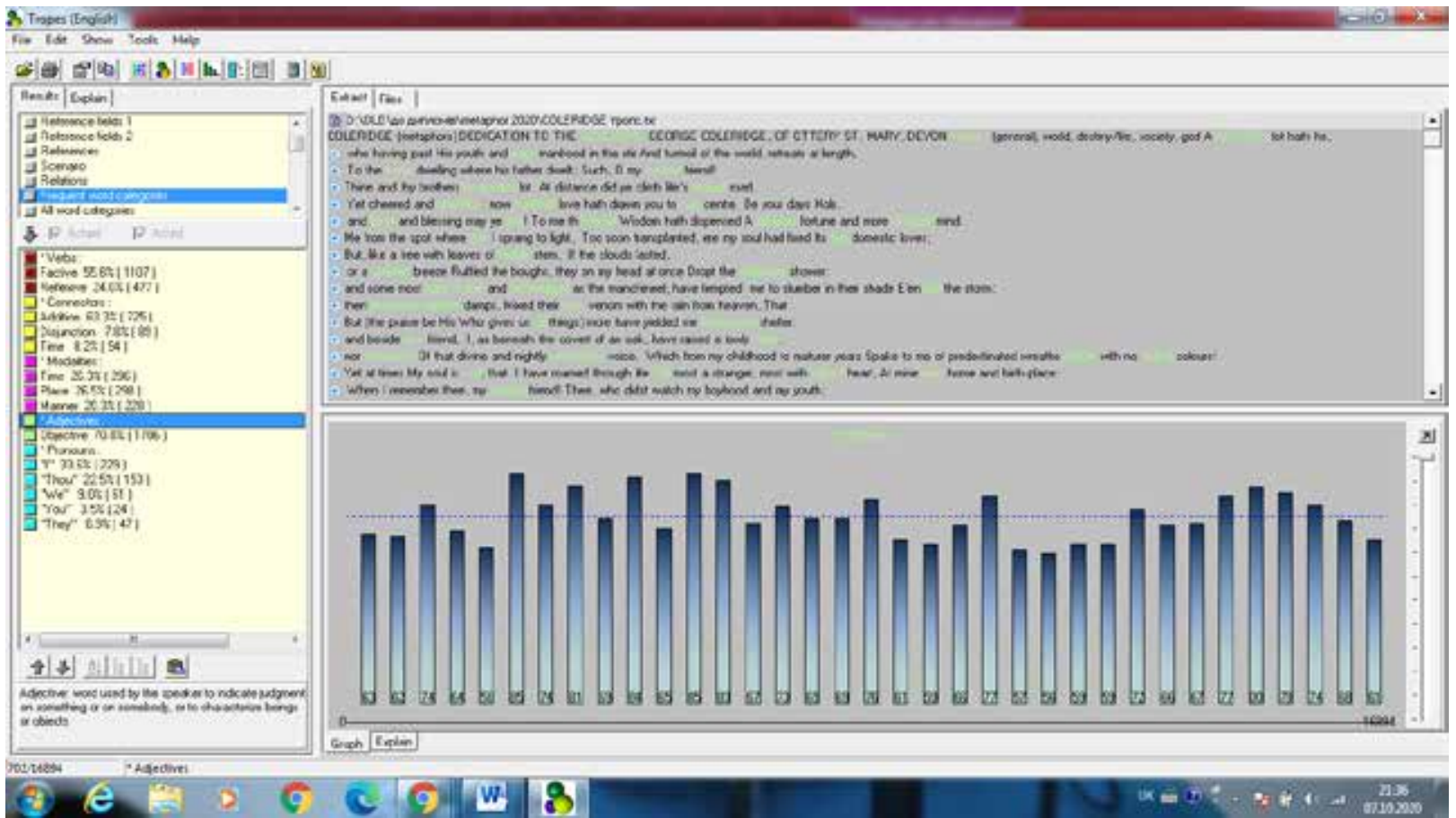

Рис. 9. Частотність прикметників у метафорах поетичного дискурсу Семюела Тейлора Колріджа Джерело: розроблено авторами 
лексем: see, hear, tell, speak, talk, feel, think, love, behold, weep, depart, sing, listen, weave, lift, rest.

Найчастотнішими прикметниками, залученими до процесу метафоризащії, виявлено лексеми, що належать до лексико-семантичних груп сенсорного сприйняття, аксіологічного відображення предмету поетизації, психоемоційного стану: sweet, soft, bright, gentle, dark, gentle, dim, blue, light, deep, happy, silver, pure, pensive, clear, warm, dark, golden, fresh, wild, crystal, tender, sad, sensitive, rich, eternal, deep, mighty, glorious, dewy, silent, fragrant, delitious, silken, sleepless, fair, feeble, starry, smooth, wavy, ethereal, dead, etc. Особливо високою є частотність прикметників-кольороназв або їх асоціатів, які мають переважно позитивну оцінно-експресивну конотованість: golden, silver, sunny, green, etc.

Висока частотність словосполук Adj. + Noun у структурі метафоричних контекстів засвідчуе продуктивність метафроричного епітету у поетичному дискурсі Колріджа. 3337 проаналізованих метафоричних контекстів практично усі містять метафоричний епітет у своїй структурі. Метафорично означуватись можуть як абстрактні, так і конкретні поняття, що також засвідчуе високу частотність семантико-когнітивної операщії мапування тих ознак концептів царини джерела на концепти царини мети (за Лакофом та Тернером), які відображають антропоцентричний характер сприйняття довкілля та художньо-поетичної його репрезентаціï, результатом якого є одухотворення предмету зображення (переважно елементів природи, когніщії, уяви, франтазіі, емоцій). Для поетики Колріджа характерним $є$ явище синестезї як єдності візуального, акустичного, сенсорного, чуттевого та раціонального сприйняття довкілля; використання фрразеологічних/лексикалізованих метарор (переважно на основі прикметників sweet, soft, deep, green), що фріксовані у народнопоетичній картині світу як сталі репрезентанти явищ довкілля, людського бут- тя та діяльності, що наповнюються новим змістом: sweet abode, sweet flower, sweet dream, soft voice, soft glow, soft soul - Sweet songsters wable in a shade their wild-long melody; Ye pine-grows, with your soft and soul-like sounds. Прикметниками, які виконують у тексті функцію і означення, і епітету, найчастіше виступають якісні прикметники, що позначають світло, колір, температуру, спосіб та стан, сенсорні відчуття: clear, dark golden, warm, cold.

За допомогою програми Tropes також було встановлено номенклатуру, частотність та дистрибуцію іменників, залучених до творення художньо-поетичної метафори (рис. 10-12).

Відповідно до частотності іменників, залучених до творення метафори, було виділено концептуальні сорери «Людина» та "Світ, природа» як такі, що представлені найбільшою кількістю метафрор. Метафори, у яких ключовим елементом $є$ іменник, було проаналізовано на предмет їх фрункціональних особливостей у структурі поетичних мікроконтекстів та лексико-семантичного наповнення. Так, іменникова метафора, залучена до художньо-поетичної концептуалізації сорери Людина - концептів людина (загалом), психоемоційна та когнітивна діяльність - найчастіше містить ключові слова: love, heart, soul, spirit, joy, dream, voice, eye, breath, mind. Іменникова метафора, залучена до художньо-поетичної концептуалізації концептуальної сорери Світ - концепту природа, природні стихії найчастіше містить ключові слова earth, sun, rock, stream, air, breeze, tree, sea, star, grove, sky. Найчастотнішим лексико-семантичним типом поетичного образу, створеного на основі цих двох груп вказаних ключових слів, є метафрора-персоніфрікація (як одухотворення об'єктів природи та абстрактних понять, так і одухотворення абстрактних понять, які означають оцінку, емоцію, стан, френомен, дію, поведінку). Тим самим здійснюеться художньо-поетичне відтворення основного

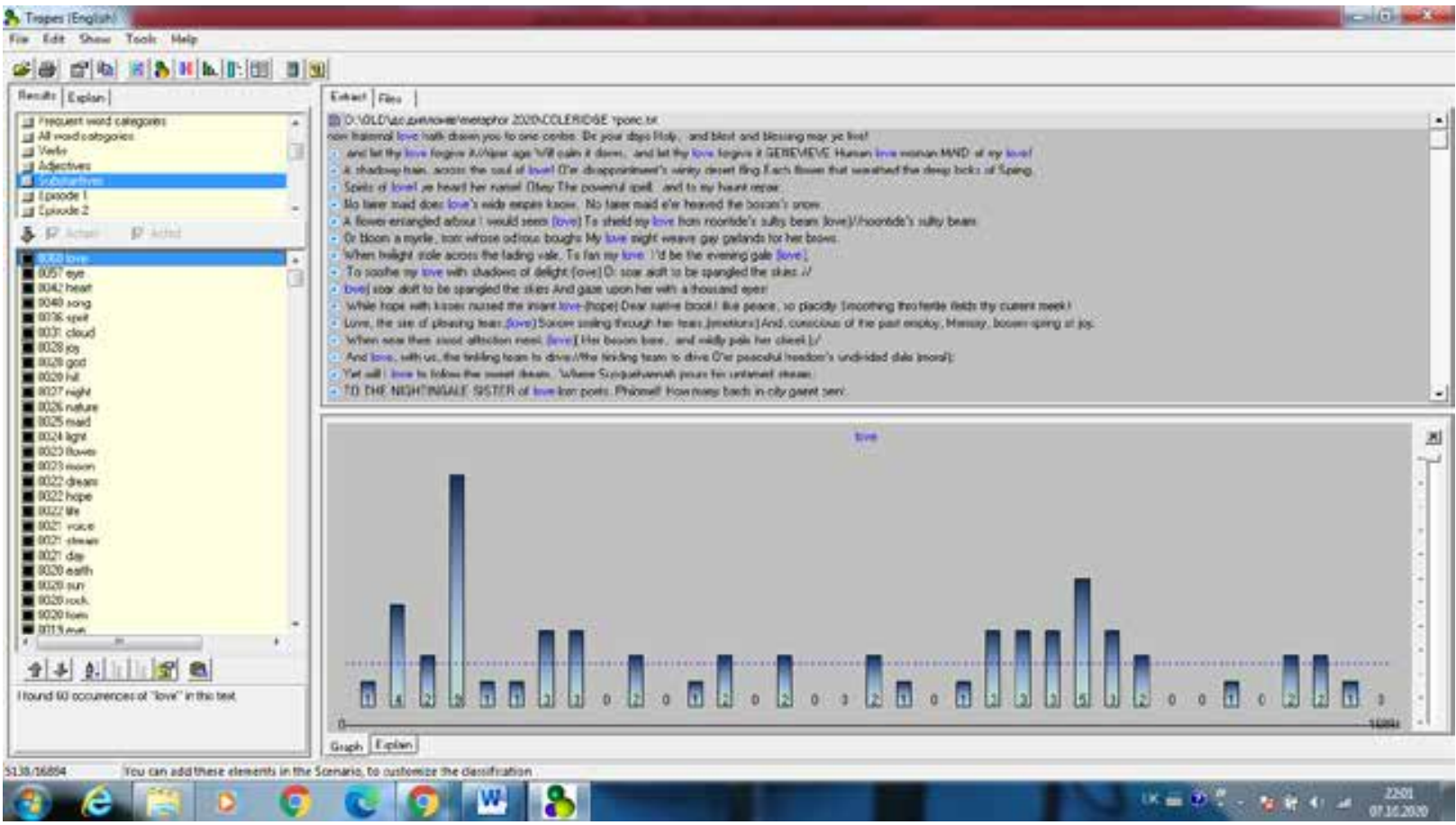

Рис. 10. Частотність лексеми love

Джерело: розроблено авторами 


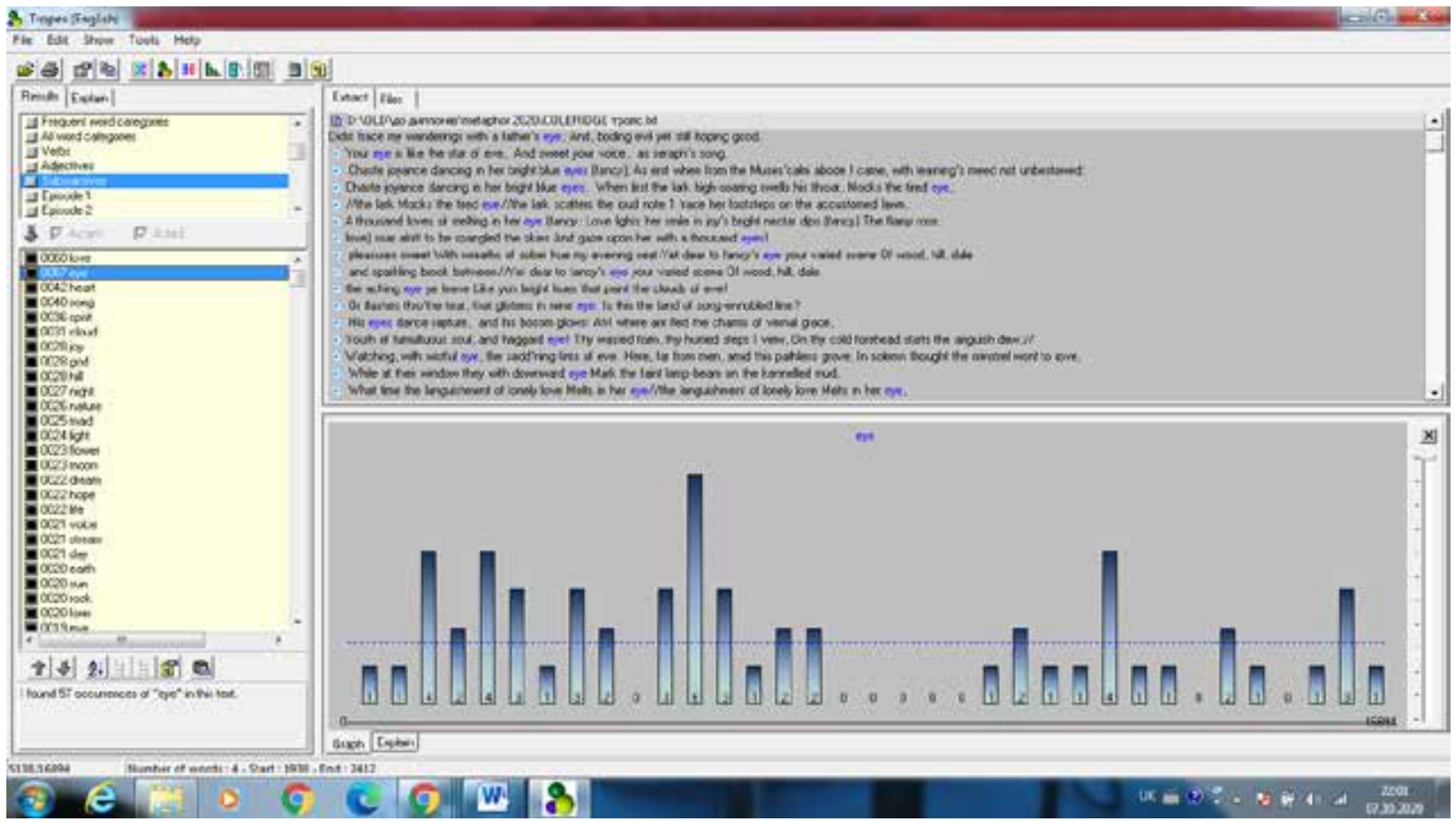

Рис. 11. Частотність лексеми еуе

Джерело: розроблено авторами

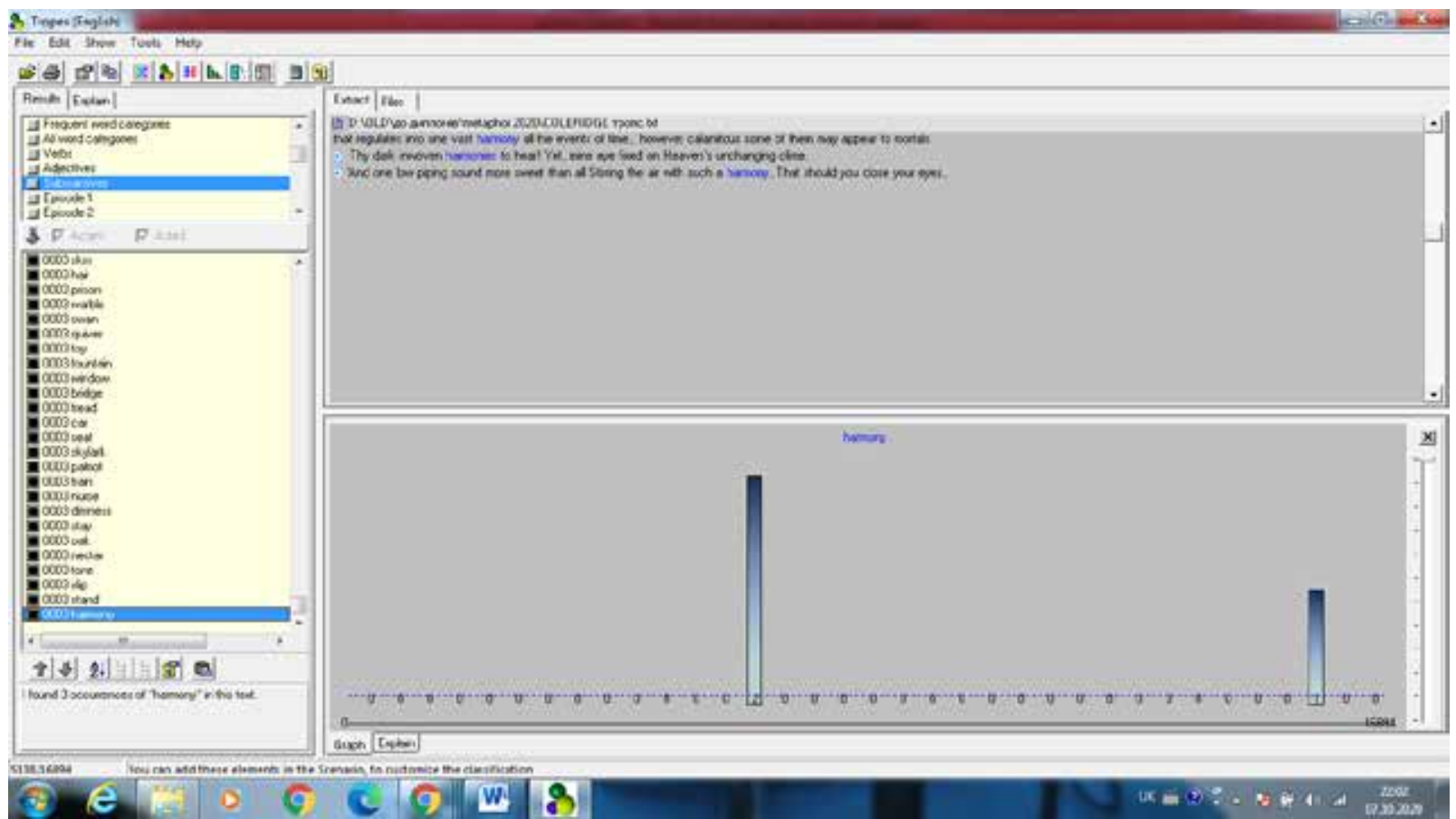

Рис. 12. Частотність лексеми harmony

Джерело: розроблено авторами

художньо-естетичного принципу романтизму антропоцентричного сприйняття довкілля.

Наступним етапом дослідження був аналіз основних метафоричних моделей концептуалізації визначених концептуальних сфрер з метою визначення характеру та особливостей поетичної картини світу Семюела Тейлора Колріджа.

Концептуальна сбера ЛЮДИНА/HUMAN. У межах ціеї концептуальної сорери було вибрано 99 мікроконтекстів, що містять метадрору. Найчас- тотнішими художньо-поетичними концептами, які метароризовані, $є$ концепт «Людина (загалом)», актуалізований метафоричними моделями:

Людина - рослина / дерево як часткова реалізація метафоричної моделі «життя $є$ розлоге дерево»: like a tree with leaves of feeble stem;

Людина - дух / легка (нестабільна) субстаниія / відлуння, тінь як часткова реалізація концептуальної метафрори «життя є вмістилище (субстанції / енергії)» та «життя є мелодія»; 
Людина - мандрівник як індивідуальноавторська реалізація концептуальної метафори та символічної асоціації «життя є шлях»: Gentle lunatic! // Worships the spirit of unconscious life. In tree or wild-flower. - Man whose heart was pierced / With the remembrance of a grievous wrong, / Or slow distemper, or neglected love / (And so, poor wretch! filled all things with himself, / And made all gentle sounds tell back the tale / Of his own sorrow).

Особлива увага у поетиці Колріджа приділена психоемоційним, когнітивним, етичним аспектам метафоризації концептосфрери Людина. Так, людські емоції метафоризовано у моделях:

Позитивна елоція - світло, сонце, пролінь, вогонь: What time the morning sun of hope arose, / And all was joy; save when another's woes / A transient gloom upon my soul imprest, soar aloft to be the spangled skies / And gaze upon her with a thousand eyes! / As when the savage, who his drowsy frame / Had basked beneath the sun's unclouded flame. His eyes dance rapture, and his bosom glows. ALL thoughts, all passions, all delights, / Whatever stirs this mortal frame, / All are but ministers of Love, / And feed his sacred flame.

Негативні елоції-хмара, тінь, речовина: soft neighbourhood of filmy clouds, / The stains and shadings of forgotten tears... save when another's woes / A transient gloom upon my soul imprest.

Метадоризація концептів "душа» та "серце» відбувається за метафоричною моделлю «вмістилище», «дія», «рух» (переважно вертикальний, вгору), «звучання», «рідина / рідка субстанція». Найчастотнішим структурно-семантичним типом метафор у таких випадках є метафртонімії та метафори-персонірккації: Shall thrill th' attuned heartstring with delight. ...my soul / Averted shudders at the poisoned bowl. ....groans my sickening heart.... feeble heart / Shall flow away like a dissolving thing. we may lift the Soul, and contemplate / With lively joy the joys we cannot share.

Чуттевість, кохання, краса - тепло, бbізична субстаниія з різноланітнили паралетралии (сили дї̈, впливу, звуку) світло / пролінь: your heavenly beauty gives / This heart with passion soft to glow: / Within your soul a voice there lives! / It bids you hear the tale of woe... In beauty's light you glide along: / Your eye is like the star of eve, / And sweet your voice, as seraph's song.

$\mathrm{y}$ поетиці Колріджа емоція чи стан ліричного героя переданий образними засобами максимального абстрагуювання та персоніфікації, виступаючи дієвою силою, наділеною енергією та здатністю діяти не залежно від волі суб'єкта: Visions of Childhood! oft have ye beguiled / Lone Manhood's cares... Ill-fated youth! / Go, day by day, and waste thy manly prime / In mad love-yearning by the vacant brook, / Till sickly thoughts bewitch thine eyes, and thou / Behold'st her shadow still abiding there. Age / Had dimmed mine eyes to blindness!

Концептуальна сфбера CBIT / WORLD. У межах ціеї концептуальної сфери було вибрано 135 мікроконтексти, що містять метафору. Художньо-поетична репрезентація світу загалом як середовища перебування і життедіяльності людини отримуе позитивну конотацію у найчастотнішій метафоричній моделі "світ - зелний рай", "світ - влістилище божественного / любові $i$ краси", "природа - лікар / учитель": All adoration of the God in nature, / All lovely and all honourable things, / Whatever makes this mortal spirit feel / The joy and greatness of its future being? Nature ... may well employ / Each faculty of sense, and keep the heart / Awake to Love and Beauty. All golden with the never-bloomless furze, / Which now blooms most profusely; but the dell, / Bathed by the mist, is fresh and delicate / As vernal cornfield, or the unripe flax, / When, through its half-transparent stalks, at eve, / The level sunshine glimmers with green light. / Oh! 'tis a quiet spirit-healing nook!

Також, найчастотнішими художньо-поетичними концептами, які метафоризовані, $е$ концепти, що відображають природні феномени, елементи природи та природні стихії, вербалізовані низкою різноструктурних метафор, серед яких чільне місце займає метафора-персоніфікація: What time the pale moon sheds a softer day, I Mellowing the woods beneath its pensive beam / For 'mid the quiv'ring light 'tis ours to play, I Aye dancing to the cadence of the stream. Or where, his silver waters smoothed to rest, The tall tree's shadow sleeps upon his breast. Where o'er the jutting rocks soft mosses creep // Or coloured lichens with slow oozing weep; / Where cypress and the darker yew start wild; / And 'mid the summer torrent's gentle dash / Dance brightened the red clusters of the ash.

Основним семантико-когнітивним формантом метафор «елелент природи - жива істо$\boldsymbol{m a} /$ людина» є ознаки руху, переміщення, когнітивних та комунікативних параметрів, фізіологічних ознак, здатності до творчої діяльності: The frost performs its secret ministry, / Unhelped by any wind; the summer clothe the general earth / With greenness while the nigh thatch / Smokes in the sun-thaw; whether the eave-drops fall, / Heard only in the trances of the blast, / Or if the secret ministry of frost / Shall hang them up in silent icicles, / Quietly shining to the quiet Moon. Активно до творення метафор-персоніфікацій залучено соматичний та акустичний коди (голос пісня, мелодія; тіло, природний об'єкт, явище музичний інструмент): ... the breezes of the simple air / Possess the power and spirit of melody... These wilds, these caverns roaming o'er / Round which the screaming sea-gulls soar, / With wild unequal steps he passed along, / Oft pouring on the winds a broken song... (Breeze) Ne'er played the wanton-never half disclosed / The maiden's snowy bosom, scattering thence / Eye-poisons for some love-distempered youth, / Who ne'er henceforth may see an aspen-grove / Shiver in sunshine.... these wakeful birds / Have all burst forth in choral minstrelsy, / As if some sudden gale had swept at once / A hundred airy harps!

Складність когнітивних процесів, що лежать в основі метафоричного змішання концептуальних доменів, відображена у високій частотності композиційної метафори, яка охоплюе багатогранні аспекти зображуваного явища, коли метафора утворена на основі переплетення та взаємодії різноманітних семантико-когнітивних формантів звукові, акустичні параметри концептів царини джерела, колористичні, акщіональні. Природні стихії, феномени, елементи не просто персоніфікуються, одухотворяються, а, максимально аб- 
страгуючись, виступають дієвим суб'єктом, одночасно поєднують такі ознаки як рух, емоційність, інтелект, комунікативна здатність, зміни стану, емоційності, що створюе високу продуктивність антропоморфної та зооморфної метафори.

Подібну антропоморфізацію об'єктів поетичного зображення спостерігаємо у метафоризації концептів, що належать концептуальним сорерам «життя», «смерть», «абстрактні поняття» «суспільство» та «бог». У метафоризації концептів «життя», «доля», «смерть» основним типом метафроричного переносу є життя - вода, життя - хлара; доля - тягар, доля - чаша, доля - шторл, zроза (So tost by storms along life's wild'ring way / Mine eye reverted views that cloudless day, / When by my native brook I wont to rove. Such were the struggles of that gloomy hour, / When care, of withered brow, / Prepared the poison's power: / Already to thy lips was raised the bowl, / When near thee stood affection meek. Roll the black tide of death thro' every freezing vein) та традищійні архетипові акщіональні метафоричні моделі «випивання рідини як прийняття невідворотності долі / cлnерmi»: Roll the black tide of death thro' every freezing vein... / .... the poisoned bowl.

Висновки. У результаті проведеного аналізу приходимо до висновку про визначальну роль метафрори у поетичній картині світу Семюела Тейлора Колріджа. Продуктивність базових метафоричних моделей, що відображають індивідуально-авторське переосмислення традиційної, архетипної образності, домінування антропоцентричного метафоричного світосприйняття, у переважанні метафори-персоніфрікащії, ускладненості структури метадори.

Кількісні дані, отримані в ході застосування відповідних інструментів комп'ютерного аналізу укладеного авторського поетичного корпусу, дозволяють охопити максимальний об'єм контекстів метафоризащії та сприяють досягненню максимальної об’єктивності дослідження.

\section{Список літератури:}

1. Белехова Л.І. Словесний поетичний образ в історико-типологічній перспективі: лінгвокогнітивний аспект (на матеріалі американської поезії). Херсон : Айлант, 2002. 367 с.

2. Бутакова Л.О. Авторское сознание в поэзии и прозе: когнитивное моделирование. Барнаул, 2001. 283 с.

3. Дьяконова Н.Я., Яковлева Г.В. Философско-эстетические воззрения С.Т. Колріджа. Колрідж С.Т. Избранные труды. Москва, 1987. С. 8-37.

4. Кравцова Ю.В. Метафорическое моделирование мира. Поэзия и проза. Киев : Изд-во НПУ им. М.П. Драгоманова, 2011. 360 с.

5. Наливайко Д.С., Шахова К.О. Зарубіжна література ХIX сторіччя. Доба романтизму : підручник. Тернопіль : Навч. книга - Богдан, 2001. 416 с

6. Abbasi Pyeaam. The Rime of the Ancient Mariner: An Ecocritical Approach. The Criterion. An International Journal in English. 2014. April. Vol. 5. Issue II.

7. Clayton J.W. Coleridge and the Logos: The Trinitarian Unity of Consciousness and Culture. Journal of Religion. 1990. Vol. 70.2. P. 213-40.

8. Corpus-based approaches to metaphor and metonymy [Edited by A. Stefanowitsch, St.Th. Gries]. Berlin, New York : Mouton de Gruyter, 2006. 319 p.

9. Esterhammer A. The Romanic Performative: Language and Action in British and German Romanticism. Stanford Univ. Press, 2001. 377 p.

10. Johnston K.R. A Modern Coleridge. Self-consciousness, social guilt, and romantic poetry: Coleridge's Ancient Mariner and Wordsworth's Old Pedlar. Beyond Representation: Philosophy and Poetic Imagination / Richard Thomas Eldridge (ed.). Cambridge Univ. Press, 1996. P. 216-248.

11. Milburn M. Coleridge's Definition of Magic and Tolkien's Definition(s) of Faery. Tolkien Studies. 2010. Vol. 7. P. 55-66. Available at: http://www.researchgate.net/publication/236744864_Coleridge's_Definition_of_Imagination_ and_Tolkien's_Definition(s)_of_Faery (accessed 27.11.2020).

\section{References:}

1. Bieliekhova L.I. (2002) Slovesnyi poetychnyi obraz v istoryko-typolohichnii perspektyvi linhvokohnityvnyi aspekt (na materiali amerykanskoi poezii) [Verbal poetic image in the historical typological oerspective (based on the modern Americal poetry]. Kherson: Ailant. (in Ukrainian)

2. Butakova L.O. (2001) Avtorskoe soznanie v poezii $i$ proze: kognitivnoe modelirovanie [Author's consciousness in the poetry and proze]. Barnaul. (in Russian)

3. D'yakonova N.Ya., Yakovleva G.V. (1987) Filosofsko-esteticheskie vozzreniya S.T. Kolridzha [Phylosophical and aesthetic conceptions of Coleridge]. Kolridzh S.T. Izbrannye trudy [Selected works]. Moscow, pp. 8-37.

4. Kravcova Yu.V. (2011) Metaforicheskoe modelirovanie mira. Poeziya i proza [Metaphoric modeling of the worls. Poetry and Proze]. Kiev: Izd-vo NPU im. M.P. Dragomanova. (in Russian)

5. Nalyvaiko D.S., Shakhova K.O. (2001) Zarubizhna Literatura XIX Storichchia. Doba Romantyzmu [Foreign Literature. The time of Romanticism]. Ternopil: Navch. knyha - Bohdan. (in Ukrainian)

6. Abbasi Pyeaam (2014) The Rime of the Ancient Mariner: An Ecocritical Approach. The Criterion. An International Journal in English. April, vol. 5, issue II.

7. Clayton J.W. (1990) Coleridge and the Logos: The Trinitarian Unity of Consciousness and Culture. Journal of Religion, vol. 70.2, pp. 213-240.

8. A. Stefanowitsch, St.Th. Gries (ed.) (2006) Corpus-based approaches to metaphor and metonymy. Berlin, New York: Mouton de Gruyter.

9. Esterhammer A. (2001) The Romanic Performative: Language and Action in British and German Romanticism. Stanford Univ. Press.

10. Johnston K.R. (1996) A Modern Coleridge. Self-consciousness, social guilt, and romantic poetry: Coleridge's Ancient Mariner and Wordsworth's Old Pedlar. Beyond Representation: Philosophy and Poetic Imagination / Richard Thomas Eldridge (ed.). Cambridge Univ. Press, pp. 216-248.

11. Milburn M. (2010) Coleridge's Definition of Magic and Tolkien's Definition(s) of Faery. Tolkien Studies, vol. 7, pp. 55-66. Available at: http://www.researchgate.net/publication/236744864_Coleridge's_Definition_of_Imagination_ and_Tolkien's_Definition(s)_of_Faery (accessed 27.11.2020). 